Shuhrat Nuritdinovich Atakhanov, Candidate of Technical Sciences, Associate Professor Namangan Engineering and Technology Institute, 7 Kasansay street, 160115, Namangan, Uzbekistan

ORCID: 0000-0002-9896-7986

Quchqar Odilovich Dodaev, Doctor of Sciences, Professor Tashkent chemical-Technology Institute, 36 Navoiy street, Tashkent, Uzbekistan ORCID: 0000-0002-9636-0101 Anvar Mahmudovich Hamdamov, Candidate of Technical Sciences, Associate Professor Namangan Engineering and Technology Institute, 7 Kasansay street, 160115, Namangan, Uzbekistan ORCID: 0000-0003-0342-4311 Bekzod Adashev, Namangan Engineering and Technology Institute, assistant 7 Kasansay street, 160115, Namangan, Uzbekistan ORCID: 0000-0003-0821-0160

\title{
STUDY AND ASSESSMENT OF QUALITY OF SEMI-FINISHED FRUIT SAUCES
}

The article considers the problems of increasing the share of consumed fruits by the country's population and one of the ways to solve this problem with increasing the assortment of consumed fruit sauces. Technologies have been developed for the preparation of a whole range of semi-finished fruit sauces. Organoleptic and physicochemical parameters of new semi-finished products are investigated. The nutritional value of new semi-finished fruit pasta sauces has been studied.

\section{Introduction}

The diet of modern man mainly covers the energy costs of the body. However, for a number of both objective and subjective reasons, it does not satisfy its need for a number of biologically active substances.

A balanced human diet largely depends on the consumption of fruits, vegetables, berries as the main sources of vitamins, trace elements, organic acids and other biologically active substances. 
It is well known that the chemical composition of fruits and berries $(1,2,3)$ is also represented by all the nutrients necessary for the human body. Fresh fruits and berries contain 75 to $95 \%$ water, while about $95 \%$ of the water is in a free-moving form and only $5 \%$ of the water in a bound state is retained by colloids $(4,5,6)$.

An important component of fruits is dry matter, their content varies between $10-20 \%$ and even up to $25 \%(5,6,7)$. A significant part of these solids are sugar carbohydrates (glucose, fructose, sucrose) polysaccharides, pectin, fiber. Most fruits do not contain fats, the amount of nitrogenous substances does not exceed $3 \%$, the minerals of the fruits are part of organic and inorganic salts, and these are mainly potassium, calcium, sodium, phosphorus, magnesium, and trace elements include honey, manganese, and iron $(8,9)$.

Of the organic acids, malic, citric, sorrel, tartaric, and phytic acids predominate in the composition of fruits. In addition to vitamins B and D (calciferol), all vitamins are contained in the fruits. Fruits are also rich in dietary fiber, pectin. Plant fibers improve the motor function of the gastrointestinal tract and contribute to the elimination of congestion in the intestines $(3,5)$. From the above it follows that fruits and berries have high nutritional value and contain all the necessary nutrients for the normal functioning of the human body. The problem requiring resolution is to increase the share of fruit consumption in the country to scientifically based physiological norms. To some extent this problem can be resolved through the catering network when it is cooperated with agricultural production.

One of the ways to solve these problems is to increase the share of consumed fruit sauces. Currently, fruit sauces are rarely prepared and used in the public catering network of our Republic, this is due to the fact that they are added in small quantities and the cooking process is time-consuming. But used in small quantities, these fruit sauces improve organoleptic characteristics and increase the nutritional value of consumed foods enriched with dietary fiber, minerals, vitamins.

Considering the above, we have developed a technology for the preparation of semi-finished sauces of apricot, plum, persimmon, raspberry $(10,11,12)$. Below are some of the technologies for semi-finished fruit sauces.

The technology for preparing a semi-finished apricot sauce turns off apricot exposure on a weak solution of ascorbic acid, microwave processing, separating the pulp and juice, concentrating the juice and dissolving the ingredients and thickeners on this juice, mixing with the pulp, rubbing, heating and packaging.

During the process of preparing a semi-finished product from plums, we kept the plum in a weak saline solution, separated the seed and heated the pulp to separate juice. Then added the thickener to the liquid part and previously prepared powder of walnut peel (the bitterness from the walnut peel is removed, then it is withstoot in sugar syrup, dried and crushed) that was dissolved connected with the pulp. All the ingidientswere mixed, wiped, heated and packaged. 
The peel of wallnut is rich in iodine, iron, and in the Ferghana Valley there is an acute shortage of iodine. The production of such iodine-rich foods helps prevent goiter and anemia among nations.

\section{Materials and research methods:}

When performing experimental work, generally accepted and standard research methods were used, those are appropriate to study organoleptic and physico-chemical indicators.

Organoleptic evaluation was conducted according to GOST (13). As the products that have been developed are new, we made up private quality standards (14). Mass fraction of lipids were estimated according to GOST (15), mass fraction of carbohydrates according to GOST (16), mass fraction of protein according to GOST (17), acidity according to GOST (18), the mass fraction of vitamin C according to GOST (19).

During the experimental work, the following materials were used: fresh apricot, fresh cream, fresh raspberry, persimmon, lemon, skimmed milk powder, dogrose, natural honey, rice starch, corn starch, potato starch, walnut peel. All materials met the requirements of OST and GOST.

\section{The results of the study}

Semi-finished fruit sauces have a complex chemical composition (fruits, fillers), especially those that have undergone technological processing, create as a so-called «spicy flavor». In order to investigate what sensations lead to the consumption of fruit sauces and semi-finished products, the profile of its properties has been made up. Figure 1. shows the taste profile of the semi-finished products of apricot and plum pasta sauces.

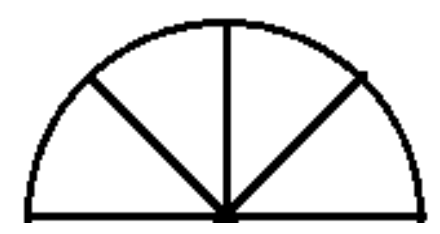

a)
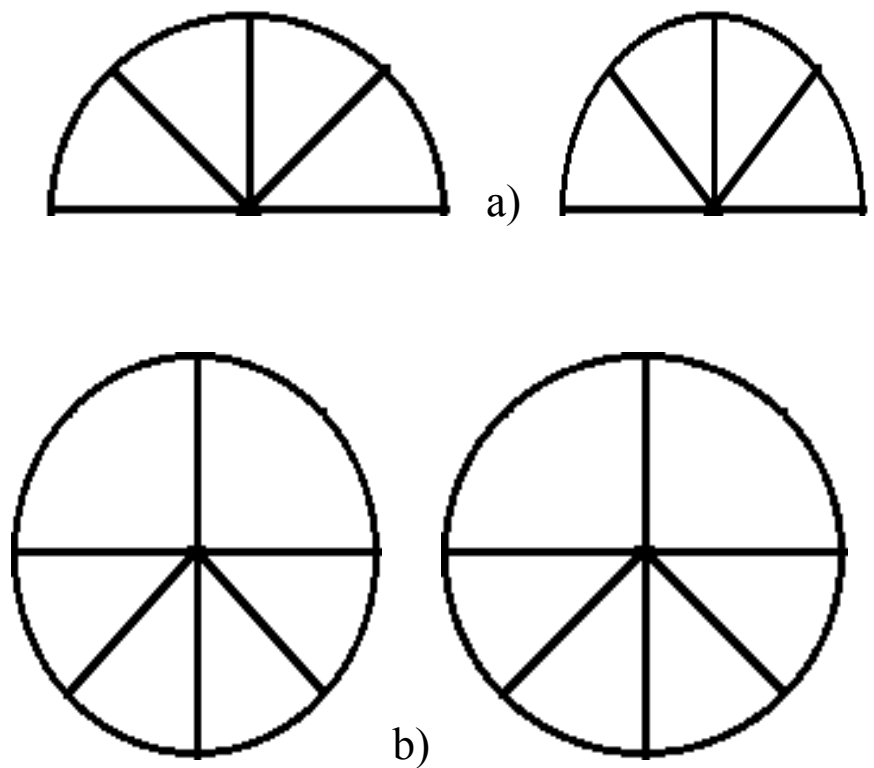

Figure 1. The construction of the taste profile of semi-finished apricot sauces (a) in the form of a semicircle, plum (b) in a full circle 
Also, according to the scoring method, the levels of partial (according to separate indicators) and total (according to a set of indicators) quality was established. We used 5 point scales using the weight coefficient (importance, significance) for individual indicators and developed a scale for the particular qualities of semi-finished fruit pasta sauces.

Tab. 1, 2.

Data on the organoleptic evaluation of semi-finished fruit sauces are given in table 2.

Table 2

\section{Organoleptic characteristics of semi-finished fruit sauces}

\begin{tabular}{|c|c|c|c|c|c|}
\hline \multirow{2}{*}{$\begin{array}{c}\text { Name of the } \\
\text { samples }\end{array}$} & \multicolumn{5}{|c|}{ Indicators } \\
\hline & Appearance & Color & Consistency & Odor & Taste \\
\hline Apricot & $\begin{array}{l}\text { Homogeneous } \\
\text { mass, without } \\
\text { surface films, } \\
\text { without lumps of } \\
\text { starch and dried } \\
\text { milk, lumpy }\end{array}$ & $\begin{array}{l}\text { Light } \\
\text { orange }\end{array}$ & $\begin{array}{c}\text { Pasty, elastic } \\
\text { mass }\end{array}$ & $\begin{array}{l}\text { Apricot, } \\
\text { pleasant } \\
\text { without } \\
\text { foreign odor }\end{array}$ & $\begin{array}{c}\text { Apricot, } \\
\text { pleasant, } \\
\text { without } \\
\text { foreign taste }\end{array}$ \\
\hline Plum & $\begin{array}{l}\text { Homogeneous } \\
\text { mass, without } \\
\text { surface films, } \\
\text { without lumps of } \\
\text { starch and dried } \\
\text { milk, lumpy }\end{array}$ & $\begin{array}{l}\text { Light } \\
\text { brown }\end{array}$ & $\begin{array}{c}\text { Pasty, elastic } \\
\text { mass }\end{array}$ & $\begin{array}{c}\text { Plum, pleasant } \\
\text { without } \\
\text { foreign odor }\end{array}$ & $\begin{array}{l}\text { Plum, } \\
\text { pleasant, } \\
\text { without } \\
\text { foreign taste }\end{array}$ \\
\hline Raspberry & $\begin{array}{l}\text { Homogeneous } \\
\text { mass, without } \\
\text { surface films, } \\
\text { without lumps of } \\
\text { starch and dried } \\
\text { milk, lumpy }\end{array}$ & Light red & $\begin{array}{c}\text { Pasty, elastic } \\
\text { mass }\end{array}$ & $\begin{array}{l}\text { Raspberry, } \\
\text { pleasant } \\
\text { without } \\
\text { foreign odor }\end{array}$ & $\begin{array}{l}\text { Raspberry, } \\
\text { pleasant } \\
\text { without } \\
\text { foreign taste }\end{array}$ \\
\hline Persimmon & $\begin{array}{l}\text { Homogeneous } \\
\text { mass, without } \\
\text { surface films, } \\
\text { without lumps of } \\
\text { starch and dried } \\
\text { milk, lumpy }\end{array}$ & $\begin{array}{l}\text { Light } \\
\text { orange }\end{array}$ & $\begin{array}{c}\text { Pasty, elastic } \\
\text { mass }\end{array}$ & $\begin{array}{l}\text { Persimmon, } \\
\text { pleasant } \\
\text { without } \\
\text { foreign odor }\end{array}$ & $\begin{array}{l}\text { Persimmon, } \\
\text { pleasant } \\
\text { without } \\
\text { foreign taste }\end{array}$ \\
\hline
\end{tabular}




\section{The scale of the private qualities of semi-finished apricot sauce}

\begin{tabular}{|c|c|c|c|c|c|}
\hline \multirow{2}{*}{$\begin{array}{l}\text { Name of } \\
\text { private } \\
\text { qualities }\end{array}$} & \multirow{2}{*}{$\begin{array}{l}\text { Importance } \\
\text { coefficient }\end{array}$} & \multicolumn{4}{|c|}{ Characteristic of private qualities, score } \\
\hline & & 5 & 4 & 3 & 2 \\
\hline $\begin{array}{l}\text { Appea- } \\
\text { rance }\end{array}$ & 2 & $\begin{array}{l}\text { Homogene } \\
\text { ous, } \\
\text { uniformly } \\
\text { wiped } \\
\text { without } \\
\text { particles } \\
\text { and seeds }\end{array}$ & $\begin{array}{c}\text { Homogeneous } \\
\text { uniformly wiped, parts } \\
\text { of seeds are observed }\end{array}$ & $\begin{array}{l}\text { Mass with } \\
\text { separate } \\
\text { lumps of } \\
\text { starch and } \\
\text { milk } \\
\text { powder with } \\
\text { particles of } \\
\text { seed }\end{array}$ & $\begin{array}{c}\text { Nonhomog } \\
\text { eneous mass } \\
\text { with lumps } \\
\text { of starch } \\
\text { and milk } \\
\text { powder, } \\
\text { particles of } \\
\text { seeds }\end{array}$ \\
\hline $\begin{array}{l}\text { Consis- } \\
\text { tency }\end{array}$ & 1 & $\begin{array}{l}\text { Pasty, } \\
\text { slightly } \\
\text { viscous }\end{array}$ & Pasty viscous & $\begin{array}{c}\text { Pasty } \\
\text { compacted. }\end{array}$ & Tight \\
\hline Color & 2 & $\begin{array}{c}\text { Dark } \\
\text { yellow }\end{array}$ & Yellow & $\begin{array}{l}\text { Light } \\
\text { yellow }\end{array}$ & $\begin{array}{l}\text { Yellowish } \\
\text { with a white } \\
\text { tint of milk }\end{array}$ \\
\hline $\begin{array}{l}\text { Вкус } \\
\text { запах }\end{array}$ & 5 & $\begin{array}{l}\text { Characterist } \\
\text { ic of this } \\
\text { type of } \\
\text { semi- } \\
\text { finished } \\
\text { product } \\
\text { with the } \\
\text { smell and } \\
\text { taste of fruit }\end{array}$ & $\begin{array}{l}\text { Characteristic of this } \\
\text { type of semi-finished } \\
\text { product taste and } \\
\text { smell of fruit is } \\
\text { pronounced }\end{array}$ & $\begin{array}{l}\text { Characterist } \\
\text { ic of this } \\
\text { type of } \\
\text { semi- } \\
\text { finished } \\
\text { product } \\
\text { with a slight } \\
\text { smack of } \\
\text { dried milk } \\
\text { starch }\end{array}$ & $\begin{array}{l}\text { Unpleasant } \\
\text { with foreign } \\
\text { matter, } \\
\text { starch } \\
\text { smack }\end{array}$ \\
\hline
\end{tabular}

The basic physical and chemical parameters of semi-finished fruit sauces were also studied together with the Institute of Plant Substances at the Academy of Sciences of the Republic of Uzbekistan.

The results of the studies are shown in table 2 . 


\section{Physico-chemical indicators and energy value of semi-finished fruit sauces}

\begin{tabular}{|c|c|c|c|c|}
\hline \multirow{2}{*}{$\begin{array}{c}\text { Main } \\
\text { characteristics }\end{array}$} & Apricot & Plum & Persimmon & Raspberry \\
\cline { 2 - 5 } & $\begin{array}{c}\text { Mass fraction } \\
\text { of } \\
\text { carbohydrates } \\
\% \text { fiber\% }\end{array}$ & $\begin{array}{c}2.8 \\
4.2\end{array}$ & $\begin{array}{c}5.8 \\
2.8\end{array}$ & $\begin{array}{c}4.5 \\
3.8\end{array}$ \\
\hline $\begin{array}{c}\text { Mass fraction } \\
\text { of lipids \% }\end{array}$ & 0.25 & - & - & 0.8 \\
\hline $\begin{array}{c}\text { Mass fraction } \\
\text { of protein\% }\end{array}$ & 2.30 & - & - & - \\
\hline $\begin{array}{c}\text { Solids content, } \\
\%\end{array}$ & 49.0 & 51.0 & 49.6 & 48.5 \\
\hline $\begin{array}{c}\text { Mass fraction } \\
\text { of vitamin C } \\
\text { mg / 100ml }\end{array}$ & 27 & 13 & 22 & 46.4 \\
\hline $\begin{array}{c}\text { Energy value } \\
\text { kcal / kzh }\end{array}$ & $22.65 / 91.79$ & $23.20 / 91.60$ & $18.00 / 70.6$ & $3.20 / 12.56$ \\
\hline Acidity & 0.65 & 0.90 & 0.80 & 0.70 \\
\hline
\end{tabular}

As can be seen from the data in Table 2, carbohydrates in semi-finished fruit sauces range from $0.8-2.8 \%$. The high carbohydrate content in semi-finished products of plum sauce $5.8 \%$ and persimmon can be explained by the high carbohydrate content in the raw materials of these semi-finished products. Carbohydrates play a huge role in the life of the human body. With their help, very important biochemical processes occur in the blood and tissues. Carbohydrates are not an integral part of the human diet, they are the main source of ensuring the energy costs of the body.

Semi-finished sauces are rich in fiber. We previously said that although fiber in the small intestine is almost not absorbed, normal digestion is almost impossible without it. Fiber creates favorable conditions for the advancement of food along the gastrointestinal tract, to some extent they play the role of pebbles that the chicken looks at when feeding. In addition, fiber normalizes the activity of beneficial intestinal microflora (especially with pectin found in fruits), helps excretion of cholesterol from the body. The maximum fiber content in the semi-finished product of apricot sauce is $4.2 \%$, the lowest indicator in the semi-finished product of raspberry sauce is $1.9 \%$. Semi-finished persimmon and plum sauces are also rich in fiber. This can be explained by the fact that the raw materials and ingredients used in the preparation of these semifinished sauces are rich in fiber. 
The lipid content of $2.25 \%$, protein $2.30 \%$ in the semi-finished product of apricot sauce is due to the fact that skim milk powder was used in the preparation of this sauce. The use of skimmed milk powder in semi-finished apricot sauce not only enhances nutritional value, but also gives the corresponding consistency to the sauce.

The study also determined acidity values. Acidity is an important parameter of food. The growth of microorganisms such as bacteria and fungi also depends on acidity. As a rule, the higher the acidity of the product, the less likely it will be spoiled by microorganisms. Acidity affects the taste, smells of the product, that is, its quality indicators, physical properties, enzyme activity and thereby determines the technological properties of the products.

The preserving properties of acidity have been known for a long time and it is used to preserve food. Another distinguishing feature of acidity with other nutrients gives products a specific, pleasant aftertaste. The highest acidity in semi-finished plum sauce is $0.9 \%$ and the lowest in apricot sauce is $0.65 \%$.

By the content of vitamin $\mathrm{C}$ among the semi-finished samples, the semifinished raspberry sauce is the leader. As you know, raspberries are rich in vitamin C and in the preparation of sauces rosehip powder was used, which is also a source of ascorbic acid.

The energy value of semi-finished fruit sauces is low, since the low indicator in raspberry sauce is $3.20, / 12.56 \mathrm{Kcal} / \mathrm{kJ}$, and in the semi-finished product of apricot and plum sauces, 22. 65/9179 and 23. 20/91. $60 \mathrm{Kcal} / \mathrm{kJ}$, respectively. These indicators meet the objectives of the research, because our goal is not to hang energy values, but rather to enrich the consumed foods with these fillers, plant fiber, pectin, vitamins and minerals.

Conclusion. The analysis shows that the assortment of fruit sauces is narrow, therefore, the development of new technologies is an urgent task. A study of the organoleptic characteristics of semi-finished fruit sauces showed that they meet the requirements for sauces. According to physicochemical parameters, they are rich in fiber from 1. 9-4. 2\%, vitamin C 13-46. $4 \mathrm{mg} / 100 \mathrm{t}$ and have low energy value, which meets the requirements and goals of this research work.

\section{REFERENCES}

1. Dotsenko V. A. Fruits in nutrition L. Lenizdat, 1988. - 189 p.

2. Nikolaeva M. A. Commodity research of fruits and vegetables. M. Economics 1990.

3. The chemical composition of food. Reference / Ed. Skurikhina I. M., Volgareva M. N. - M.: Agropromizdat. 1987. - 224 p. T. 2.

4. Mark A. T., Zykina T. F., Golubev V. N. Technochemical control of canning production M: Agropromizdat. 1989. - 304 p. 
5. Mark A. T. Biochemistry of preservation of fruits of vegetables. - M. : Food Industry, 1973. $-371 \mathrm{p}$.

6. Reference merchandiser of food products in 2 volumes of T-2 / Avt. koll: Baranova E. N., Borovikova A. A. and Dr. R. / -M. : Economics 1987-319 p.

7. Kretovich V. L. Plant Biochemistry, Moscow: Higher School, 1980. -445 p.

8. Metlitsky L. V. Fundamentals of biochemistry. - M. : Economics. 1976. $334 \mathrm{~s}$.

9. Widely T. S., Yarashevich I. V. Biochemistry and quality of fruits. - Minsk. Science and Technology. 1991. $-294 \mathrm{p}$.

10. The method of preparation of semi-finished apricot sauce (Atakhanov Sh. N, Akramboev R. A., Rakhimov U. Yu, Adizov. A. Zh., Israilov R. I., Rakhimov. N. N., (UZ). Notification of admission applications / AR 20280382 dated August 3, 2018.

11. A method of preparing an iodine-prepared semi-finished product of plum sauce O. O. Mamatkarimov, Sh. N. Atakhanov, R. A. Akramboev, Sh. A. Zhalilova, BT Abdullaev, Sh. Sh. Otakhanov (UZ) Notice of acceptance of the application / AR 20180536 from 11.11.2018.

12. The method of preparation of prefabricated persimmon sauce. Sh. N. Atakhanov, K. O. Dodaev, R. A. Akramboev, U. R. Nishonov, M. N. Abdurazzakova, Sh. Sh. Otakhanov (UZ) Notice of acceptance of the application 20180260 14. 06. 2019 year

13. GOST 1503972. Products of fruits and vegetables. Organoleptic analysis.

14. GOST ISO 2173. Products of processing fruits and vegetables. Refractometric method for the determination of solids.

15. GOST 8756. 21 Products of processing fruits and vegetables. Fat Methods.

16. GOST 8756. 21 Products of processing fruits and vegetables. Methods for the determination of carbohydrates.

17. GOST 25011. Meat and meat products. Method for determination of protein.

18. GOST 255555. Products of processing fruits and vegetables. Definitions of titratable acidity.

19. GOST 24556. Products of processing fruits and vegetables. Methods for determining vitamin $\mathrm{C}$. 